
при хроническом простатите / синдроме хронической тазовой боли

\author{
Кульчавеня Е.В., ${ }^{1 *}$, Шевченко С.Ю., ${ }^{1,2}$ Баранчукова А.А., \\ ${ }^{1}$ ФББУ «Новосибирский НИИ туберкулеза» Минздрава России

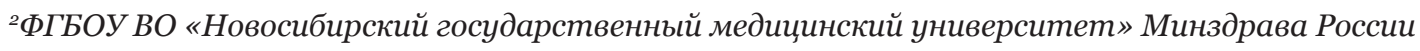

\title{
Possibilities of extracorporeal shock wave therapy in chronic prostatitis / chronic pelvic pain syndrome
}

Kulchavenya E.V. ${ }^{1,2 *}$, Shevchenko S.Yu. ${ }^{1,2}$, Baranchukova A.A. ${ }^{1,2}$

${ }^{1}$ Novosibirsk Reseach Institute of Tuberculosis

${ }^{2}$ Novosibirsk State Medical University

\begin{abstract}
АННОТАЦИЯ
Хронический простатит (ХП) - широко распространенное заболевание, склонное к рецидивам и развитию осложнений. В исследовании, посвященном оценке возможностей экстракорпоральной ударно-волновой терапии (ЭУВТ), участвовало 100 больных ХП, из них у 73 ХП был осложнен камнями предстательной железы. У всех больных в комплекс лечения входила ЭУВТ на установке Dornier Aries. Результаты лечения оценивали по шкале симптомов XП NIH - CPSI (National Institutes of Health - Chronic Prostatitis Symptom Index) и по степени литолизации. Непосредственно по окончании курса ЭУВТ положительная динамика у больных ХП была несущественной: количество баллов по шкале симптомов суммарно снизилось с 20.5 до 18.0, однако через месяц среднее число баллов уменьшилось в среднем до 9.8. Через 3 мес после ЭУВТ в комбинации с фитотерапией препаратом канефрон н у 67.9 \% больных ХП, осложненным простатолитиазом, секрет простаты был санирован; на 86.7 \% снизилась интенсивность боли, на $65.2 \%$ - степень нарушения мочеиспускания, на 60.9 \% - уровень литолизации предстательной железы. ЭУВТ, выполняемая на аппарате Dornier Aries, высоко эффективна у больных ХП категории IIІа, b и при простатолитиазе.
\end{abstract}

Ключевъе слова: хронический простатит, доброкачественная гиперплазия предстательной железы, трансректальное ультразвуковое исследование, дистанционная ударно-волновая терапия, простатолитиаз, камни простаты, экстракорпоральная ударно-волновая терапия, туберкулез простаты, фитотерапия, канефрон н, урогенитальные инфекции.

\begin{abstract}
Chronic prostatitis (CP) is a common condition that predispose to recurrence and development of complications. The 100 patients with CP participated in the research devoted to assessment of opportunities of the extracorporeal shock wave therapy (ESWT). 73 of them have had CP complicated with prostatic calculi. All patients have had ESWT complex treatment on the "Dornier Aries". The results of treatment were estimated on a scale of CP symptoms called NIH - CPSI (National Institutes of Health - Chronic Prostatitis Symptom Index) and on prostatolithiasis level. Course patients with CP had insignificant positive dynamics immediately after ESWT: the number of points on a scale of symptoms totally decreased from 20.5 to 18.0, however the mean points decreased on average up to 9.8 in a month. The secretion of prostate was debrided in $67.9 \%$ of CP patients with complicated prostatolithiasis in 3 months after ESWT combined with phytotherapy by drug canephron $\mathrm{n}$; the amount of pain has decreased for $86.7 \%$, urination disturbance level - for $65.2 \%$, prostatolithiasis level - for $60.9 \%$. ESWT peformed on "Dornier Aries" is highly effective in patients with CP of IIIa, b category and in prostatolithiasis.
\end{abstract}

Keywords: chronic prostatitis, benign prostatic hyperplasia, transrectal ultrasonography, prostatolithiasis, prostatic calculi, extracorporeal shock wave therapy, prostate tuberculosis, phytotherapy, canephron n, urogenital infections.

Поступила 09.04.2018

Принята 28.04.2018

* Автор, ответственный за переписку

Кульчавеня Екатерина Валерьевна: ФГБОУ ВО «Новосибирский государственный медицинский университет» Минздрава России. 630091,

г. Новосибирск, Красный просп., 52.

E-mail: urotub@yandex.ru
Received 09.04.2018 Accepted 28.04.2018

*Corresponding author

Kulchavenya Ekaterina Valeryevna: Novosibirsk State Medical University, 52, Krasny Prospect, Novosibirsk, 630091, Russia.

E-mail: urotub@yandex.ru 


\section{ВВЕДЕНИЕ}

Хронический простатит / синдром хронической тазовой боли (ХП / СХТБ) широко распространен в мужской популяции [1]. ХП / СХТБ имеет как медицинское, так и социальное значение, существенно влияет на качество жизни мужчины [2]. Заболевание имеет тенденцию к хроническому, непрерывно-рецидивирующему течению, что подтверждается отсутствием высокоэффективной унифицированной терапии и делает актуальными попытки поиска новых методов воздействия [3].

В структуре ХП преобладают абактериальные формы заболевания - категории IIIa и IIIb по классификации National Institutes of Health (NIH). Если с лечением больных бактериальным ХП тактика понятна и основана на антибиотиках, то с терапией больных абактериальным ХП (категории IIIа и IIIb), или СХТБ, подходы к лечению не так однозначны. Руководства рекомендуют назначать больным ХП / СХТБ анальгетики, нестероидные противовоспалительные препараты, $\alpha$-адреноблокаторы $[4,5]$, но эффективность их невысока. В последнее время появились данные о применении акупунктуры, гипертермии, фитотерапии при ХП / СХТБ [6, 7]. Учитывая большое количество лекарственных средств, которые принимает городской житель - среднестатистический мужчина среднего возраста, включая биологически активные добавки и препараты по поводу сопутствующих заболеваний, оправдано стремление современной медицины шире применять немедикаментозные методы воздействия.

Ультразвуковое исследование предстательной железы по поводу простатита, рака, доброкачественной гиперплазии нередко выявляет в различных отделах паренхимы множественные плотные тени, трактуемые обычно как конкременты (камни) предстательной железы, или простатолитиаз. Камни предстательной железы часто сопровождают хронический простатит, в том числе туберкулезной этиологии [8-10] (в данной ситуации тени, интерпретируемые как конкременты, фактически являются очагами посттуберкулезного обызвествления), поддерживают очаг хронической инфекции в предстательной железе [11].

Сами по себе камни предстательной железы лечения не требуют, однако существенно осложняют течение сопутствующего простатита, препятствуют достижению стойкой ремиссии и, за счет непрерывного раздражения окружающих тканей, могут привести к малигнизации. Однако вопрос терапии больных простатолитиазом остается открытым.

\section{INTRODUCTION}

Chronic prostatitis / chronic pelvic pain syndrome (CP / CPPS) is widespread in male population [1]. CP / CPPS have both medical, and social value, influences on male life quality significantly [2]. The disease tends to chronic, continuous recurrent attack that was confirmed by lack of the highly effective unified therapy and makes attempts of searching for new methods of influence relevant [3].

Abacterial forms of disease - category IIIa and IIIb on classification of National Institutes of Health (NIH) prevail in CP structure. If management of patients with bacterial $\mathrm{CP}$ is clear and based on antibiotics, the therapy of patients with abacterial CP (category IIIa and IIIb), or CPPS, methods of treatment are widely different. The guidelines recommend to prescribe analgetics, non-steroidal anti-inflammatory drugs, $\alpha$-adrenoblockers $[4,5]$ to patients with CP / CPPS, but their efficiency is low. Recently data on acupunctures, hyperthermias, phytotherapies using in patients with CP / CPPS were revealed [6, 7]. Considering a large amount of medicines taken by the city dweller, the average man of middle age, including dietary supplements and drugs concerning associated diseases, the intention of modern medicine to apply non-drug methods more widely is justified.

Ultrasound of prostate concerning prostatitis, cancer, benign hyperplasia quite often reveal the multiple dense shadows treated usually as concrements (calculi) of prostate, or prostatolithiasis in various departments of parenchyma. Prostatic calculi often accompany chronic prostatitis, including a tubercular etiology [8-10] (in this case the shadows interpreted as concrements, actually are the centers of a post-tubercular calcification) and support the center of chronic infection in prostate [11].

Prostatic calculi do not demand treatment in themselves, however it can significantly complicate the course of accompanying prostatitis, interfere with permanent remission and, at the expense of a continuous sensatation of surrounding tissues, can lead to a malignancy. However, the issue of therapy of patients with prostatolithiasis remains open.

\section{AIM OF THE RESEARCH}

To carry out the analysis of efficiency concerning extracorporeal shock wave therapy (ESWT) performed on "Dornier Aries" in patients with CP and also the combined treatment (a three-component medication canephron $\mathrm{n}$ and ESWT) in patients with $\mathrm{CP}$ associated with prostatic calculi. 


\section{ЦЕЛЬ ИССЛЕДОВАНИЯ}

Провести анализ эффективности экстракорпоральной ударно-волновой терапии (ЭУВТ), проведенной на аппарате Dornier Aries, у больных XП, а также комбинированного лечения (трехкомпонентный лекарственный препарат канефрон н и ЭУВТ) больных ХП, ассоциированным с камнями предстательной железы.

\section{МАТЕРИАЛЫ И МЕТОДЫ}

Всего в исследование включено 100 пациентов: 27 больных ХП категории IIIb для оценки эффективности ЭУВТ при ХП / СХТБ (1-я группа) и 73 пациента с ХП категории IIIа и камнями предстательной железы, визуализируемыми при трансректальном ультразвуковом исследовании (ТРУЗИ) (2-я группа). Критерии включения для 1-й группы: отсутствие инфекции в секрете простаты и эякуляте, оценка по шкале симптомов XП NIH - CPSI (Chronic Prostatitis Symptom Index) 15 баллов и более, согласие пациента на участие в исследовании. Критерии включения для 2-й группы: те же, что и для группы 1, и дополнительно наличие в нативном препарате секрета простаты, полученном путем изгоняющего массажа предстательной железы, не менее 15 лейкоцитов в поле зрения при световой микроскопии, а также подтверждение простатолитиаза посредством ТРУЗИ.

Критерии исключения для обеих групп были идентичны: наличие очага активного инфекционного воспаления любой локализации, онкологические заболевания, эндокринные и соматические заболевания в стадии декомпенсации, перенесенные операции и травмы в области промежности, завершившиеся формированием грубых рубцов, активные заболевания кожи с выраженным экссудативным компонентом в зоне проекции, тяжелые формы геморроя в стадии обострения.

Критерием эффективности в 1-й группе была динамика баллов по шкале симптомов XП NIH CPSI, у больных 2-й группы дополнительно оценивали санацию секрета предстательной железы и степень литолизации простаты, которую определяли в градации по шкале: о - нет конкрементов, 1 - единичные конкременты в парауретральной области, 2 - множественные конкременты в парауретральной области, 3 - множественные конкременты в парауретральной области и периферической зоне.

Всем больным 1-й группы проводили ЭУВТ в качестве монотерапии 2 раза в неделю, на курс 6 процедур. Параметры воздействия определяли

\section{MATERIALS AND METHODS}

In general 100 patients were included into research: 27 patients with CP of IIIb category for assessment of efficiency of ESWT at HP / CPPT (the 1st group) and 73 patients with CP of IIIa category and calculi of prostate visualized at transrectal ultrasonography (TUS) (the 2nd group). Criteria of including into the 1st group: absence of infection in prostatic secretion and ejaculate, assessment on NIH - Chronic Prostatitis Symptom Index (CPSI) of 15 points and more, informed consent of the patient to participation in a research. Criteria of including into the 2nd group: the same, as for the first group, and in addition existence in the native preparation of prostatic secretion received by prostate massage, not less than 15 leucocytes under light microscopy and also confirmation of prostatolithiasis by means of TUS.

Criteria of an exception for both groups were identical: existence of the center of active infectious inflammation of any localization, oncologic diseases, endocrine and somatic diseases in decompensation stages, the undergone operations and injuries in perineal region that resulted in deep scars, active diseases of skin with the expressed exudative component in projection zone, severe forms of hemorrhoids in the exacerbation stage.

Dynamics of points on NIH - CPSI was criterion of efficiency in the 1st group, in patients of the 2nd group in addition estimated sanation of prostatic secretion and prostatic litholisation degree that was determined in gradation according to a scale: $\mathrm{o}-$ there are no concrements, $1-$ single concrements in paraurethral zone, 2 - multiple concrements in paraurethral zone, 3 - multiple concrements in paraurethral zone and in peripheric zone.

All patient in the 1st group were performed ESWT as monotherapy 2 times a week, as a course of 6 procedures. Parameters of influence were defined individually, based on the feelings of the patient. Treatment has always began with the $5^{\text {th }}$ energy level; if the patient didn't feel the specific pulsing influence, energy was enlarged to that level at when the procedure didn't discomfort, but it was physically felt. Only one patient have the first feelings appeared at the 9th level of energy, the other ones were performed the procedure at the $5-7$ th level of energy. Therefore, patients received at least 2000 impulses for a session. ESWT was carried out by means of the device called "Dornier Aries" (Dornier MedTech Systems GmbH, Germany). The proce- 
индивидуально, основываясь на ощущениях пациента. Начинали всегда с 5-го уровня энергии; если больной не ощущал специфического пульсирующего воздействия, энергию увеличивали до того уровня, при котором процедура не доставляла дискомфорта, но физически чувствовалась. Только у одного пациента первые ощущения появились на 9-м уровне энергии, остальным процедуру выполняли на 5-7-м уровне энергии. Соответственно, пациенты получали как минимум 2000 импульсов за сеанс. ЭУВТ осуществляли посредством аппарата Dornier Aries (Dornier MedTech Systems GmbH, Germany). Процедуру всем пациентам обеих групп выполняли следующим образом. Пациент располагался в гинекологическом кресле. Манипулу смазывали гелем для ультразвуковых процедур, плотно прижимали к промежности. Примерно половину волн пациент получал при статичном положении манипулы (рис. 1), а половину - при сканирующих движениях в зоне проекции простаты от периферии к центру. Процедура при правильном выполнении безболезненна и даже комфортна, не требует никакой подготовки или ограничений для больного.

Результаты лечения оценивали по завершении курса из 6 процедур, что занимало 3 нед, а также повторно через 1 мес после окончания ЭУВТ.

Пациенты 2-й группы методом случайных чисел были распределены в три подгруппы: подгруппа 2а (23 пациента) получала канефрон н по 1 драже трижды в день в течение месяца; пациентам подгруппы 2b (22 чел.) проведено 8 сеан- dure to all patients of both groups was performed as follows. The patient sat down in a gynecologic chair. The handpiece was greased with gel for ultrasonic procedures, densely pressed to perineal region. The patient received about a half of waves at the static provision of the handpiece (Fig. 1), and half - at the scanning movements in a prostate projection zone from the periphery to the center. At the correct performance the procedure is painless and even comfortable, it doesn't demand any preparation or restrictions for the patient.

Results of treatment were estimated upon completion of a course consisting from 6 procedures that took 3 weeks. Also, it was repeated in 1 month after the ESWT cessation.

Patients of the 2nd group were distributed in three subgroups by random number generation: the subgroup 2a (23 patients) received canephron $n$ 1 dragee three times a day within a month; patients of subgroup $2 b$ (22 people) received 8 sessions of ESWT on the "Dornier Aries"; the subgroup 2c (28 patients) received ESWT against canephron n. All the inspection was carried out prior to therapy, in 4 weeks (upon the end of treatment) and in 3 months after the end of treatment.

ESWT was carried out in the same mode, as in the 1st group, but, considering prostatolithiasis to be the complicating factor for $\mathrm{CP}$, the number of procedures was enlarged to 8 within four weeks. The results were estimated in one and in three months after the end of treatment.

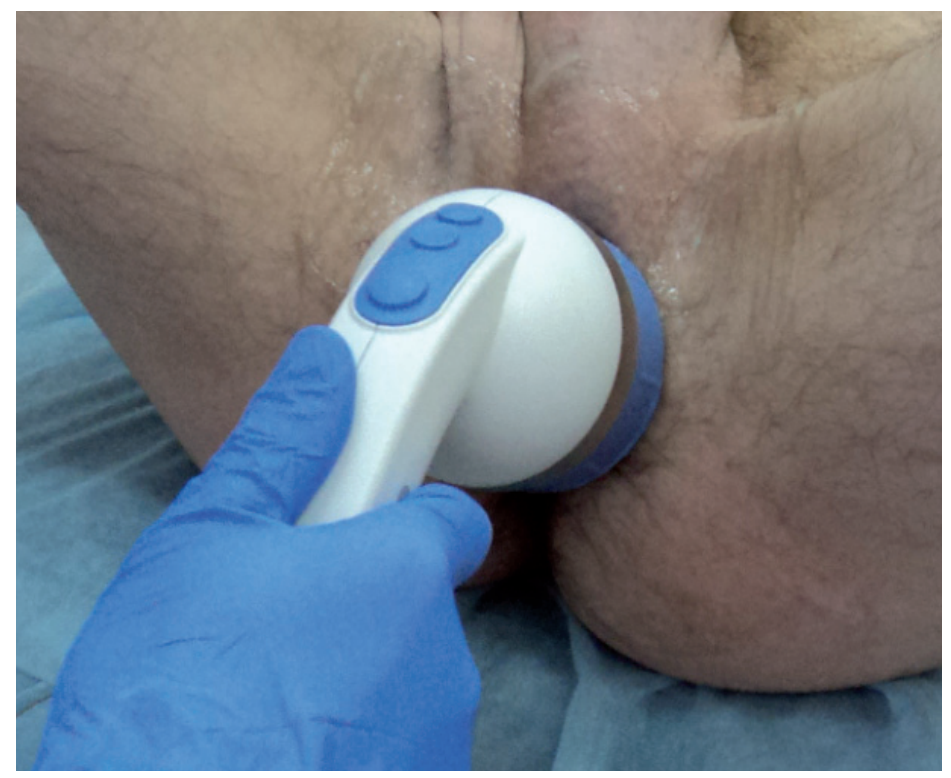

Рис. 1. Расположение манипулы при проведении ЭУВТ больному ХП Fig. 1. A handpiece location during ESWT in CP patient 
сов ЭУВТ на установке Dornier Aries; подгруппа 2с (28 больных) получала ЭУВТ на фоне приема канефрона н. Весь комплекс обследования проводили до начала терапии, через 4 нед (по завершении курса лечения) и через 3 мес после завершения курса лечения.

ЭУВТ выполняли в том же режиме, что и в 1-й группе, но, учитывая, что простатолитиаз является осложняющим фактором для ХП, число процедур увеличили до 8 в течение четырех недель. Результаты оценивали через один и три месяца после завершения терапии.

Статистическая обработка результатов проведена на персональном компьютере с помощью пакетов статистических программ Microsoft Exсе1 2007 и Statistica for Windows 6.o. Определяли среднюю арифметическую $(x)$, отклонение от средней арифметической $(x-x)$, затем рассчитывали среднеквадратическое отклонение (б) и среднюю ошибку относительной величины $(m)$. Для решения вопроса о случайности расхождений наблюдаемых средних (относительных) величин производили расчет средней ошибки разности двух средних. Полученные результаты представляли как среднее \pm ошибка средней $(M \pm m)$. Далее посредством сравнения средних значений двух выборочных совокупностей (M1 и M2) вычисляли $t$-критерий Стьюдента и определяли уровень значимости $p$. Статистически значимыми считали различия при $p<0.05$.

\section{РЕЗУЛЬТАТЫ И ОБСУЖЛДЕНИЕ}

В 1-й группе непосредственно по окончании курса ЭУВТ положительная динамика была несущественной: по шкале симптомов NIH - CPSI суммарно количество баллов снизилось с 20.5 до 18.0 ( $p$ > 0.05). Однако через 1 мес выраженность боли уменьшилась в среднем до 3.2 балла, интенсивность нарушений мочеиспускания - в среднем до 2.7 балла, средняя оценка качества жизни составила 3.9 балла; суммарный средний балл -9.8 $(p<0.05)$ (табл. 1).
Statistical processing of results was carried out on the personal computer by such statistical packages as Microsoft Exce1 2007 and Statistica for Windows 6.0. Arithmetical average $(x)$, deviation from arithmetical average $(x-x)$ were defined. Then mean-square deviation $(\sigma)$ and average error of the relative size $(\mathrm{m})$ were counted. The calculation of an average error of difference of two averages was made to resolve the issue of accident of divergences concerning the observed average (relative) sizes. The received results were presented as an average \pm an error of average $(M \pm m)$. Then Student's $t$-test was estimated by means of comparison of average values of two samples (M1 and $M 2$ ) and significance level of $p$ was defined. The differences at $p<0.05$ were considered statistically significant.

\section{RESULTS AND DISCUSSION}

Positive dynamics in the 1st group immediately upon the end of ESWT course was insignificant: on a scale of symptoms of NIH - CPSI the number of points totally decreased from 20.5 to 18.0 ( $p>0.05$ ). However the expression of pain decreased on average up to 3.2 points in 1 month, also the intensity of disturbances of urination - on average up to 2.7 points, average assessment of life quality was 3.9 points; resulting average score -9.8 ( $p<0.05)$ (Table 1).

Thus, the final result to ESWT in CP takes time; the lack of immediate effect should not disappoint the doctor and the patient. Reliable improvement of all indicators from valid scale of symptoms is registered in a month.

The intensity of pain prior to treatment in subgroup $2 \mathrm{a}$ averaged 8.9 points, in subgroups $2 \mathrm{~b}$ and $2 \mathrm{c}$ point -9.2 and 9.0 respectively. Patients of subgroups 2a estimated disturbance of urination on average at 4.5 points, in subgroups $2 b$ and $2 c-4.3$ and 4.6 points respectively. The quality of life on a

Таблица 1. Эффективность ЭУВТ у больных ХП / СХТБ $(n=27)$

Table 1. ESWT efficiency in patients with CP / CPPS $(n=27)$

\begin{tabular}{llll}
\hline $\begin{array}{l}\text { Домен шкалы / Index Domain } \\
\text { NIH - CPSI }\end{array}$ & Исходно / Initially & $\begin{array}{l}\text { По завершении курса ЭУВТ } \\
\text { Upon the end of course ESWT }\end{array}$ & $\begin{array}{l}\text { Через 1 мес после ЭУВТ } \\
\text { In month after ESWT }\end{array}$ \\
\hline Боль / Раin & $9.1 \pm 0.7$ & $7.9 \pm 0.6$ & $3.2 \pm 0.3^{*}$ \\
Нарушение мочеиспускания & $4.2 \pm 0.4$ & $4.1 \pm 0.4$ & $2.7 \pm 0.3^{*}$ \\
$\begin{array}{l}\text { Disturbance of urination } \\
\text { Качество жизни / Quality of life }\end{array}$ & $7.2 \pm 1.1$ & & $3.9 \pm 0.5^{*}$ \\
Сумма баллов / Total score & $20.5 \pm 0.8$ & $18.0 \pm 1.1$ & $9.8 \pm 0.9^{*}$ \\
\hline
\end{tabular}

* Различие достоверно.

The difference is significant. 
Таким образом, для окончательного ответа на ЭУВТ при ХП требуется время; отсутствие непосредственного эффекта не должно огорчать врача и пациента. Через месяц по всем показателям валидной шкалы симптомов отмечено достоверное улучшение.

Интенсивность боли до начала лечения в подгруппе 2а составила в среднем 8.9 балла, в подгруппах $2 b$ и $2 c-9.2$ и 9.0 балла соответственно. Нарушение мочеиспускания больные подгруппы $2 a$ оценили в среднем в 4.5 балла, в подгруппах $2 b$ и $2 c-$ в 4.3 и 4.6 балла соответственно. Качество жизни по шкале симптомов в среднем составило 7.6, 7.7 и 7.9 балла в подгруппах 2a, 2b и 2с соответственно. Сумма баллов колебалась от 21.0 до 21.5. Степень литолизации в среднем определили по подгруппам $2 \mathrm{a}, 2 \mathrm{~b}$ и $2 \mathrm{c}-2.3,2.4$ и вновь 2.3 балла соответственно. Статистически значимых различий не выявлено, группы идентичны по клиниколабораторным характеристикам.

Через месяц по завершении монотерапии в подгруппах 2a и $2 \mathrm{~b}$ и комбинированного лечения в подгруппе 2c отмечена динамика по всем параметрам с разной степенью направленности и достоверности (табл. 2). Как следует из таблицы, прием канефрона н почти у 2/3 пациентов привел к санации секрета предстательной железы, сумма баллов по шкале NIH - CPSI снизилась ниже диагностически значимой, что свидетельствует о купировании воспаления. Улучшились параметры мочеиспускания, однако эхоскопические характеристики предстательной железы остались без изменения.

Курс ЭУВТ - как монотерапия, так и в сочетании с канефроном н - не позволил нормализовать число лейкоцитов в секрете предстательной железы. Сумма баллов по шкале NIH - CPSI в подгруппе 2b по-прежнему превышала 15, однако проведение ЭУВТ в сочетании с канефроном н позволило добиться снижения суммы баллов до 14.1. В подгруппах $2 \mathrm{~b}$ и $2 \mathrm{c}$ также было отмечено уменьшение объема предстательной железы и степени ее литолизации.

Данные, полученные при контрольном обследовании через 3 мес после завершения курса лечения, представлены в табл. 3 .

По-прежнему у более половины пациентов подгруппе 2а сохранялось нормальное количество лейкоцитов в секрете простаты; на четверть уменьшилось число больных с лейкоцитозом секрета в подгруппе $2 \mathrm{~b}$ и на две трети - у больных, получавших комбинированное лечение. Во всех группах снизилось общее количество баллов по шкале NIH - CPSI ниже диагностического мини- scale of symptoms averaged 7.6, 7.7 and 7.9 points in subgroups $2 \mathrm{a}, 2 \mathrm{~b}$ and $2 \mathrm{c}$ respectively. Score fluctuated from 21.0 to 21.5. Litholisation degree was determined on average by subgroups $2 \mathrm{a}, 2 \mathrm{~b}$ and $2 \mathrm{c}-$ 2.3, 2.4 and again 2.3 points respectively. No significant difference was found, groups are identical according to clinical laboratory data.

Dynamics over all factors with different degree of orientation and reliability (Table 2) were registered in a month after the end of monotherapy in subgroups $2 \mathrm{a}$ and $2 \mathrm{~b}$ and the combined treatment in subgroup 2c. As appears from the table, the intake of canephron $n$ almost at $2 / 3$ patients resulted in sanation of prostate secretion, the score on $\mathrm{NIH}$ - CPSI scale decreased below diagnostically significant variations that showed inflammation arresting. Urination parameters improved, however echoscope features of prostate did not differ.

ESWT as monotherapy, and combined with canephron $\mathrm{n}$ - didn't allow to normalize the number of leucocytes in prostate secretion. Score on a scale of NIH - CPSI in subgroup 2b still exceeded 15, however ESWT combined with canephron $\mathrm{n}$ allowed to achieve depression of score up to 14.1. The decrease of volume of prostate and degree of its litholisation were also registered in subgroups $2 \mathrm{~b}$ and $2 c$.

The data obtained at follow-up examination in 3 months after the end of course of treatment are presented in Table 3 .

Still the normal quantity of leucocytes in a prostate secretion was preserved among half of the patients in subgroup 2a; the number of patients with leukocytosis of secretion in subgroup $2 b$ decreased on a quarter, and so did by two thirds in the patients receiving the combined treatment. In all groups the total of points of NIH - CPSI scale decreased diagnostic minimum, the most significant one was in subgroup of 2c. Canephron $n$ did not make any litholitical effect neither right after treatment, nor in the subsequent observation, however ESWT monotherapy, and especially ESWT combined with phytotherapy, resulted in reliably significant dropping of litholisation degree.

Experience of using extracorporal shock wave therapy exceeds 20 years. A series of domestic and foreign researches showed that the influence of shock waves promotes acceleration of formation of osteal callosity and accretion of fractures, faster adhesion of dermal wounds, results in intensifying of regenerative and reparative processes and stimulation of metabolism in tissues and cells and also 
Таблица 2. Исследуемые параметры в трех подгруппах 2-й группы больных ХП, ассоциированным с простатолитиазом, через 4 нед после лечения $(n=73)$

Table 2. The studied parameters in three subgroups of the 2nd group of patients with $\mathrm{CP}$, associated with prostatolithiasis, in 4 weeks after treatment $(n=73)$

\begin{tabular}{|c|c|c|c|}
\hline Показатель / Indicator & $\begin{array}{l}\text { Подгруппа 2а }(n=23) \text { : } \\
\text { канефрон н } \\
\text { Subgroup 2a }(n=23) \text { : } \\
\text { canephron } \mathrm{n}\end{array}$ & $\begin{array}{l}\text { Подгруппа 2b }(n=22) \text { : } \\
\text { ЭУВТ } \\
\text { Subgroup 2b }(n=22) \text { : } \\
\text { ESWT }\end{array}$ & $\begin{array}{l}\text { Подгруппа 2c }(n=28) \text { : } \\
\text { канефрон н }+ \text { ЭУВТ } \\
\text { Subgroup 2c }(n=28) \text { : } \\
\text { canephron } \mathrm{n}+\text { ESWT }\end{array}$ \\
\hline $\begin{array}{l}\text { Лейкоцитоз секрета простаты более } \\
15 \text { клеток, число больных (\%) } \\
\text { Leukocytosis of prostate secretion more } \\
\text { than } 15 \text { cells, number of patients (\%) }\end{array}$ & $8(34.8)^{*}$ & $22(100.0)$ & $27(96.4)$ \\
\hline $\begin{array}{l}\text { Боль, баллы (динамика) } \\
\text { Pain, points (dynamics) }\end{array}$ & $6.3(-2.6)^{*}$ & $8.1(-1.1)$ & $6.4(-2.6)^{* *}$ \\
\hline $\begin{array}{l}\text { Нарушение мочеиспускания, баллы } \\
\text { (динамика) } \\
\text { Disturbance of urination, points } \\
\text { (dynamics) }\end{array}$ & $2.3(-2.2)$ & $2.7(-1.6)$ & $2.6(-2.0)$ \\
\hline $\begin{array}{l}\text { Качество жизни, баллы (динамика) } \\
\text { Quality of life, points (dynamics) }\end{array}$ & $4.9(-2.7)$ & $5.0(-2.7)$ & $5.1(-2.8)$ \\
\hline $\begin{array}{l}\text { Сумма баллов, всего (динамика) } \\
\text { Total score, in all (dynamics) }\end{array}$ & $13.5(-7.5)$ & $15.8(-5.4)$ & $14.1(7.4)$ \\
\hline $\begin{array}{l}\text { Степень литолизации предстатель- } \\
\text { ной железы по данным ТРУЗИ, бал- } \\
\text { лы (динамика) } \\
\text { Prostate litholisation degree according } \\
\text { to TUS, points (dynamics) }\end{array}$ & $2.3(0.0)$ & $2.0(-0.4)^{*}$ & $1.9(-0.4)^{* * *}$ \\
\hline
\end{tabular}

* Различие достоверно между подгруппами 2а и $2 b$.

The differerence is significant between subgroups $2 \mathrm{a}$ and $2 \mathrm{~b}$.

** Различие достоверно между подгруппами 2b и 2c.

The differerence is significant between subgroups $2 \mathrm{~b}$ and $2 \mathrm{c}$.

*** Различие достоверно между подгруппами 2а и 2c.

The differerence is significant between subgroups $2 \mathrm{a}$ and $2 \mathrm{c}$.

мума, наиболее существенно - в подгруппе 2c. Канефрон н не оказал литолитического эффекта ни сразу после лечения, ни в последующем наблюдении, однако монотерапия ЭУВТ, и особенно ЭУВТ в сочетании с фитотерапией, привели к достоверно значимому понижению степени литолизации.

Опыт применения экстракорпоральной ударно-волновой терапии превышает 20 лет. Серия отечественных и зарубежных исследований показала, что воздействие ударных волн способствует ускорению образования костной мозоли и срастания переломов, более быстрому заживлению кожных ран, приводит к усилению регенеративно-репаративных процессов и стимуляции метаболизма в тканях и клетках, а также оказывает выраженный обезболивающий эффект при хронической боли различной этиологии [12]. ЭУВТ успешна в стимуляции регресса избыточного фиброза, в частности, при болезни Пейрони [13]. Широко применяется ЭУВТ в лечении больных эректильной дисфункцией. Положительный эффект подтвержден результатами двой- provides the expressed analgesic effect in chronic pain of various etiology [12]. ESWT is successful in stimulation of regress of excess fibrosis, in particular, in case of Peyronie's disease [13]. ESWT is widely applied in treatment of patients with erectile dysfunction. The positive effect is confirmed by results of randomized double blind placebo control studies [14].

The classical shock waves used in medical therapeutic practice is extremely short, potent impulse with high amplitudes of pressure and small components of stretching. At ESWT shock waves are generated out of the patient's body and are transferred deep into the body. Depending on a mode of exposure, disintegration of urinary concrements, arresting the pain, putting off a muscular spasm, revascularization of cardiac muscle after myocardial infarction can be pointed out as a result [14]. ESWT is popular in cosmetology as it gives to noticeable smoothing of cellulite. Blood flow increases in a zone of ESWT influence that eventually leads 
Таблица 3. Исследуемые параметры в трех подгруппах 2-й группы больных ХП, ассоциированным с простатолитиазом, через 12 нед после лечения $(n=73)$

Table 3. The studied parameters in three subgroups of the 2nd group of patients with $\mathrm{CP}$, associated with prostatolithiasis, in 12 weeks after treatment $(n=73)$

\begin{tabular}{|c|c|c|c|}
\hline Показатель / Indicator & $\begin{array}{l}\text { Подгруппа 2а }(n=23) \text { : } \\
\text { канефрон } \mathrm{H} \\
\text { Subgroup 2a }(n=23) \text { : } \\
\text { canephron } \mathrm{n}\end{array}$ & $\begin{array}{l}\text { Подгруппа 2b }(n=22) \text { : } \\
\text { ЭУВТ } \\
\text { Subgroup 2b }(n=22) \text { : } \\
\text { ESWT }\end{array}$ & $\begin{array}{l}\text { Подгруппа 2c }(n=28) \text { : } \\
\text { канефрон н }+ \text { ЭУВТ } \\
\text { Subgroup } 2 \mathrm{c}(\mathrm{n}=28) \text { : } \\
\text { canephron } \mathrm{n}+\text { ESWT }\end{array}$ \\
\hline $\begin{array}{l}\text { Лейкоцитоз секрета простаты более } \\
15 \text { клеток, число больных (\%) } \\
\text { Leukocytosis of prostate secretion more } \\
\text { than } 15 \text { cells, number of patients (\%) }\end{array}$ & $10(43.5)^{*}$ & $16(72.7)$ & $9(32.1)^{* * *}$ \\
\hline $\begin{array}{l}\text { Боль, баллы (динамика от исходно- } \\
\text { го) } \\
\text { Pain, points (dynamics of initial) }\end{array}$ & $3.4(-5.5)^{* *}$ & $2.8(-6.4)^{*}$ & $1.2(-7.8)^{* * *}$ \\
\hline $\begin{array}{l}\text { Нарушение мочеиспускания, баллы } \\
\text { (динамика от исходного) } \\
\text { Disturbance of urination, points } \\
\text { (dynamics of initial) }\end{array}$ & $1.8(-2.7)$ & $1.9(-2.4)$ & $1.6(-3.0)$ \\
\hline $\begin{array}{l}\text { Качество жизни, баллы (динамика } \\
\text { от исходного) } \\
\text { Quality of life, points (dynamics of } \\
\text { initial) }\end{array}$ & $2.9(-4.7)$ & $2.7(-5.0)$ & $2.5(-5.4)$ \\
\hline $\begin{array}{l}\text { Сумма баллов, всего (динамика) } \\
\text { Total score, in all (dynamics of initial) }\end{array}$ & $8.1(-12.9)$ & $7.4(-13.8)$ & $5 \cdot 3(-16.2)^{* * *}$ \\
\hline $\begin{array}{l}\text { Степень литолизации предстатель- } \\
\text { ной железы по данным ТРУЗИ, бал- } \\
\text { лы (динамика от исходного) } \\
\text { Prostate litholisation degree according } \\
\text { to TUS, points (dynamics of initial) }\end{array}$ & $2.3(0.0)^{* * *}$ & $1.3(-1.1)$ & $0.9(-1.4)^{* * *}$ \\
\hline
\end{tabular}

* Различие достоверно между подгруппами 2а и $2 b$.

The differerence is significant between subgroups $2 \mathrm{a}$ and $2 \mathrm{~b}$.

** Различие достоверно между подгруппами 2а и 2c.

The differerence is significant between subgroups $2 \mathrm{a}$ and $2 \mathrm{c}$.

*** Различие достоверно между подгруппами 2b и 2c.

The differerence is significant between subgroups $2 \mathrm{~b}$ and $2 \mathrm{c}$.

ного слепого плацебо-контролируемого рандомизированного исследования [14].

Классические ударные волны, используемые в медицинской терапевтической практике, - это чрезвычайно короткий, мощный импульс с высокими амплитудами давления и малыми компонентами растяжения. При ЭУВТ ударные волны генерируются вне тела пациента и передаются вглубь тела. В зависимости от режима воздействия, в результате происходят дезинтеграция мочевых конкрементов, купирование боли, снятие мышечного спазма, реваскуляризации сердечной мышцы после инфаркта миокарда [14]. ЭУВТ популярна в косметологии, поскольку приводит к заметному разглаживание целлюлитных отложений. В зоне воздействия ЭУВТ усиливается кровообращение, что в конечном счете ведет к улучшению обмена веществ в тех областях, которые по своей природе плохо снабжаются кровью. to improvement of metabolism in those areas with poor circulation.

It is believed, that ESWT mechanism is caused by restoration of permeability of cellular membranes. Healthy cells have an elastic membrane with normal permeability, at inflammation the structure of membrane changes, it becomes intense because of intracellular edema. The soft tissues consisting for $80 \%$ of water pass energy of the focused shock wave. Passing through elastic membranes of cells, the shock wave does not destroy them. The swollen changed membranes of the inflamed cells come in a resonance with it and are blasted due to cavitation. Thus, the focused shock wave works selectively: healthy cells pass its energy, and inflamed - die [15]. Advantages of ESWT are larger intervals between sessions (shock wave therapy is carried out on average 1 time in $5^{-7}$ days), small duration of sessions (the procedure takes $10-15 \mathrm{~min}$ ), lack of need for 
Полагают, что механизм действия ЭУВТ обусловлен восстановлением проницаемости клеточных мембран. Здоровые клетки имеют эластичную мембрану с нормальной проницаемостью, при воспалении структура мембраны изменяется, она становится напряженной из-за внутриклеточного отека. Мягкие ткани, состоящие на 80 \% из воды, пропускают энергию сфокусированной ударной волны. Проходя через эластичные мембраны клеток, ударная волна не разрушает их, а натянутые из-за отека измененные мембраны воспаленных клеток входят в резонанс с ней и разрушаются за счет эффекта кавитации. Таким образом, сфокусированная ударная волна действует избирательно: здоровые клетки пропускают ее энергию, а воспаленные - гибнут [15]. Плюсами ЭУВТ являются большие интервалы между сеансами (ударно-волновая терапия проводится в среднем 1 раз в 5-7 дней), малая продолжительность сеансов (процедура занимает 10-15 мин), отсутствие необходимости в дополнительных инъекциях и анестезии. Общие противопоказания - нарушение свертываемости крови, воздействие на область злокачественного процесса, на очаг гнойного процесса, эпифизарные зоны у подростков, беременность [15]. Осложнений при применении ЭУВТ, по данным отечественных и зарубежных публикаций, не наблюдалось.

Были проанализированы три хорошо организованных клинических исследования по оценке эффективности ЭУВТ при ХП с общим числом пациентов 157. Отмечена хорошая переносимость процедуры ЭУВТ и высокая эффективность, в том числе и в отдаленном периоде [16]. Изучали эффективность ЭУВТ у больных ХП / СХТБ после серии неудач других методов лечения. Пациенты в течение месяца получали ЭУВТ (2500 импульсов) еженедельно. Контрольный осмотр выполняли через 2 нед, 6 мес и один год после завершения ЭУВТ. Результат оценивали по шкалам: NIH - CPSI, International Prostate Symptom Score (IPSS), American Urological Association Quality of Life Due to Urinary Symptoms (AUA QOL_US) и International Index of Erectile Function (IIEF). Выявлено, что у всех пациентов был получен положительный эффект по изучаемым параметрам, который сохранялся в течение всего периода наблюдения (12 мес) [17].

Патофизиология формирования СХТБ при ХП еще не до конца изучена, тем не менее нейропатический компонент и влияние мышечного спазма признаются многими исследова- additional injections and anesthesia. The general contraindications are disturbance of blood coagulability, impact on the area with malignant process, impact on the center of purulent process, epiphyseal zones in adolescents, pregnancy [15]. Complications at ESWT, according to domestic and foreign publications, were not observed.

Three well-organized clinical trials according to efficiency of ESWT in CP were analysed with the total number of 157 patients. The good tolerance of the ESWT procedure and high efficiency including in the remote period [16] was revealed. The efficiency of ESWT in patients with CP/CPPS after a series of failures of other methods of treatment was studied. Patients received ESWT within a month (2500 impulses) weekly. Control examination was carried out in 2 weeks, 6 months and one year after the end of ESWT. The result was estimated on the following scales: NIH - CPSI, International Prostate Symptom Score (IPSS), American Urological Association Quality of Life Due to Urinary Symptoms (AUA QOL_US) and International Index of Erectile Function (IIEF). It was revealed that all patients have had the positive effect in the studied parameters and it remained during the entire period of observation (12 months) [17].

The pathophysiology of CPPS formation at CP is not well-studied, nevertheless the neuropathic component and influence of muscular spasm are admitted many researchers [18, 19]. Assuming that ESWT takes out a muscular spasm [20], M.A. Pontari, M.R. Ruggieri have proved this method of influence in CP/CPPS [21]. It is supposed that the electropneumatical waves influencing a prostate are transperineally transformed to biochemical signals (a so-called mechanotransduction) that hyperstimulate nociceptors and interrupt nervous impulse of painful sensitivity. At the same time, ESWT generates cavitational bubbles that, in turn, leads to formation of secondary power waves (so-called microstreams). It enlarges local microvascularization [22]. There is a possibility, that this phenomenon causes the delayed effect of ESWT in patients with CP / CPPS that was noted by many researchers $[17,23]$.

Still the selection of regimen is carried out empirically, there is no formula of calculation of individual dose of ESWT for the patient. All researchers registered good ESWT tolerance. It was shown that, ESWT in patients with CP / CPPS is effective [17] when all possibilities of standart therapy are exhausted. 
телями $[18,19]$. Предполагая, что ЭУВТ снимает мышечный спазм [20], M.A. Pontari, M.R. Ruggieri обосновывали этот метод воздействия при ХП / СХТБ [21]. Предполагают, что электропневматические волны, воздействующие на простату трансперинеально, трансформируются в биохимические сигналы (так называемая механотрансдукция), которые гиперстимулируют ноцицепторы и прерывают нервный импульс болевой чувствительности. Вместе с тем ЭУВТ генерирует кавитационные пузырьки, которые, в свою очередь, приводят к образованию вторичных энергетических волн (так называемые микроструи), что увеличивает локальную микроваскуляризацию [22]. Вероятно, этот феномен обусловливает отсроченный эффект ЭУВТ у больных ХП / СХТБ, что отмечали многие исследователи $[17,23]$.

До сих пор подбор режима осуществляется эмпирически, нет формулы расчета индивидуальной дозы ЭУВТ для пациента. Все исследователи отмечают хорошую переносимость ЭУВТ. Было показано, что, когда возможности рутинной терапии исчерпаны, ЭУВТ у пациентов с ХП / СХТБ эффективна [17].

A. Moayednia et al. выполнили ЭУВТ 40 больным СХТБ [23]. X. Qin, Y.P. Lu эмпирически выбрали дозу в 3000 импульсов еженедельно в течение месяца. Непосредственные результаты обнадеживали, однако через 24 нед средний балл шкалы симптомов вернулся к прежнему уровню. ЭУВТ приводила к снижению боли у 83 \% пациентов с болезнью Пейрони, существенно улучшала эректильную функцию, была эффективна у больных ХП / СХТБ, особенно выраженно по домену «боль» [24].

Монотерапия канефроном н - комплексным лекарственным средством, в состав которого входят золототысячник, любисток и розмарин, больных хроническим простатитом категории IIIa и камнями предстательной железы в течение месяца не оказывает литолитического действия и не влияет на объем предстательной железы, но на 65.2 \% снижает интенсивность воспаления, вдвое сокращает нарушение мочеиспускания, оцениваемое по шкале NIH - CPSI, на треть улучшает качество жизни и уменьшает интенсивность боли. Через три месяца после монотерапии позитивная динамика в целом сохранилась; отмечено дальнейшее уменьшение боли.

Әкстракорпоральная ударно-волновая терапия больных хроническим простатитом категории IIIа и камнями предстательной железы (8 сеансов на курс) не позволила санировать секрет предстательной железы и показала умеренный
ESWT was performed in 40 patients with CPPS by A. Moayednia et al. [23]. X. Qin, Y.P. Lu empirically chose a dose in 3000 impulses weekly within a month. Short-term results were positive, however in 24 weeks the average point of a scale of symptoms returned to the previous level. ESWT resulted in depression of pain in $83 \%$ of patients with Peyronie's disease, significantly improved erectile function, was effective in patients with CP / CPPS, and especially expressed on the "pain" domain [24].

Monotherapy of canephron $\mathrm{n}$ and complex medicine with centaury, lovage and rosemary, in patients with chronic prostatitis of category IIIa and prostatic calculi within a month has no litholitical effect and doesn't influence prostate volume. But it reduces intensity of inflammation by $65.2 \%$, decrease the disturbance of urination estimated on a scale of NIH - CPSI on a third by half improves quality of life and reduces intensity of pain. Positive dynamics remained in three months after monotherapy in general; further decrease of pain is registered.

Extracorporeal shock wave therapy in patients with chronic prostatitis of category IIIa and prostatic calculi ( 8 sessions on a course) did not allow to sanify prostate secretion and showed moderate therapeutic effect: the intensity of pain decreased by $11.9 \%$, the urination improved for $37.2 \%$, the volume of prostate decreased by $11.3 \%$, lithiasis degree - for $16.7 \%$. However, in three months the intensity of pain decreased already by $69.6 \%$, disturbance of urination - for $55.8 \%$, and lithiasis degree decreased almost twice.

The combined treatment by three-component medicinal phytodrug combined with extracorporal shock wave therapy was the most effective in patients with chronic prostatitis of category IIIa and prostatic calculi. In a month of treatment, the raised number of leucocytes was still present in prostate secretion almost in all patients. That is explained by the mechanism of ESWT action. However, in three months the prostate secretion in this group was debrided in $67.9 \%$ of patients; for $86.7 \%$ the intensity of pain decreased. Also, the degree of urination disturbance decreased by $65.2 \%$ and prostatic lithiasis degree - for $60.9 \%$.

\section{CONCLUSION}

As a monotherapy ESWT on the "Dornier Aries" resulted to double decrease of symptoms in patients with CP/CPPS. The most effective is complex of phytotherapy with canephron $\mathrm{n}$ and ESWT 
терапевтический эффект: интенсивность боли снизилась на $11.9 \%$, мочеиспускание улучшилось на $37.2 \%$, объем предстательной железы уменьшился на $11.3 \%$, степень литолизации - на 16.7\%. Однако через три месяца интенсивность боли уменьшилась уже на 69.6 \%, нарушение мочеиспускания - на $55.8 \%$, а степень литолизации снизилась почти вдвое.

Комбинированное лечение трехкомпонентным лекарственным фитопрепаратом в сочетании с экстракорпоральной ударно-волновой терапией оказалось наиболее эффективным у больных хроническим простатитом категории IIIа и камнями предстательной железы. Через месяц лечения повышенное число лейкоцитов по-прежнему присутствовало в секрете простаты почти у всех пациентов, что объясняется механизмом действия ЭУВТ. Однако через три месяца у 67.9 \% больных секрет простаты в этой группе был санирован; на $86.7 \%$ снизилась интенсивность боли, на $65.2 \%$ степень нарушения мочеиспускания и на $60.9 \%-$ уровень литолизации предстательной железы.

\section{СПИСОК ЛИТЕРАТУРЫ}

1. Krhen I., Skerk V., Schönwald S., Mareković Z. Classification, diagnosis and treatment of prostatitis syndrome // Lijec. Vjesn. 2002. Vol. 124 (3-4). P. 8998.

2. McNaughton-Collins M., MacDonald R., Wilt T.J. Diagnosis and treatment of chronic abacterial prostatitis: a systematic review // Ann. Intern Med. 2000. Vol. 133. P. 367-381.

3. Doiron R.C., Tripp D., Tolls V., Nickel J.C. The evolving clinical picture of chronic prostatitis/chronic pelvic pain syndrome (CP/CPPS): A look at 1310 patients over 16 years // Can. Urol. Assoc. J. 2018 Jun. Vol. 12 (6). doi: $10.5489 /$ cuaj.4876.

4. Anothaisintawee T., Attia J., Nickel J.C. Management of chronic prostatitis/chronic pelvic pain syndrome: a systematic review and network meta-analysis // J. Am. Med. Assoc. 2011. Vol. 305 (1). P. 78-86.

5. Nickel J.C., Krieger J.N., McNaughton-Collins M. Alfuzosin and symptoms of chronic prostatitis chronic pelvic pain syndrome // N. Engl. J. Med. 2008. Vol. 359 (25). P. 2663-2673.

6. Cai T., Tamanini I., Kulchavenya E. et al. The role of nutraceuticals and phytotherapy in the management of urinary tract infections: What we need to know? // Arch. Ital. Urol. Androl. 2017. Vol. 89 (1). P. 1-6.

7. Capodice J.L., Bemis D.L., Buttyan R., Kaplan S.A., Katz A.E. Complementary and alternative medicine for chronic prostatitis/chronic pelvic pain syndrome // Evid. Based Complement. Altern. Med. 2005. Vol. 2. P. 495-501.

8. Кульчавеня Е.В., Ковешникова Е.Ю., Жукова И.И. Клинико-эпидемиологические особенности современного туберкулезного спондилита // Туберкулёз и болезни лёгких. 2013. Т. 90, № 1. С. 41-45.

9. Осадчий А.В., Кульчавеня Е.В., Рейхруд Т.А. и др. Социально-демографическая характеристика боль- in treatment of patients with of category IIIa and prostatic calculi. The immediate results showed reliable improvement only on a series of parameters, the final effect should be estimated in three months.

Conflict of interest. The authors declare no conflict of interest.

\section{ЗАКЛЮЧЕНИЕ}

ЭУВТ на установке Dornier Aries как монотерапия приводит к двукратному уменьшению симптомов у больных ХП / СХТБ. В лечении больных ХП категории IIIа и камнями предстательной железы наиболее эффективным является комплексноеприменение фитотерапии канефроном н и ЭУВТ. Ближайшие результаты демонстрируют достоверное улучшение лишь по ряду параметров, окончательный эффект следует оценивать через три месяца.

Конфликт интересов. Авторы заявляют об отсутствии конфликта интересов.

\section{REFERENCES}

1. Krhen I., Skerk V., Schönwald S., Mareković Z. (2002). Classification, diagnosis and treatment of prostatitis syndrome. Lijec. Vjesn, 124, 3-4, 89-98.

2. McNaughton-Collins M., MacDonald R., Wilt T.J. (2000). Diagnosis and treatment of chronic abacterial prostatitis: a systematic review. Ann. Intern. Med., 133, $367-381$.

3. Doiron R.C., Tripp D., Tolls V., Nickel J.C. (2018, Jun). The evolving clinical picture of chronic prostatitis/ chronic pelvic pain syndrome (CP/CPPS): A look at 1310 patients over 16 years. Can. Urol. Assoc. J., 12, 6, 196-202. doi: 10.5489/cuaj.4876.

4. Anothaisintawee T., Attia J., Nickel J.C. (2011). Management of chronic prostatitis/chronic pelvic pain syndrome: a systematic review and network metaanalysis. J. Am. Med. Assoc., 305, 1, 78-86.

5. Nickel J.C., Krieger J.N., McNaughton-Collins M. (2008). Alfuzosin and symptoms of chronic prostatitis - chronic pelvic pain syndrome. N. Engl. J. Med., 359, 25, 2663-2673.

6. Cai T., Tamanini I., Kulchavenya E. et al. (2017). The role of nutraceuticals and phytotherapy in the management of urinary tract infections: What we need to know? Arch. Ital. Urol. Androl., 89, 1, 1-6.

7. Capodice J.L., Bemis D.L., Buttyan R., Kaplan S.A., Katz A.E. (2005). Complementary and alternative medicine for chronic prostatitis/chronic pelvic pain syndrome. Evid. Based Complement. Altern. Med., 2, 495-501.

8. Kulchavenya E.V., Koveshnikova E.Yu., Zhukova I.I. (2013). Clinical and epidemiological features of modern tuberculous spondylitis. Tuberculosis and Lung Diseases, 90, 1, 41-45. In Russ.

9. Osadchiy A.V., Kulchavenya E.V., Reykhrud T.A. (2015). Social and demographic characteristic of suf- 
ных туберкулезом легких и внелегочных локализаций // Туберкулез и болезни легких. 2015. № 2. C. $46-48$.

10. Кульчавеня Е.В., Хомяков В.Т. Туберкулез внелегочной локализации в Западной Сибири // Туберкулез и болезни легких. 2003. Т. 80, № 4. С. 13-15.

11. Zhao W.P., Li Y.T., Chen J. et al. Prostatic calculi influence the antimicrobial efficacy in men with chronic bacterial prostatitis // Asian J. Androl. 2012 Sep. Vol. 14 (5). P. 715-719. doi: 10.1038/aja.2012.40.

12. Шевелева Н.И., Тарасова Н.В. Применение ударноволновой терапии при постинсультных спастических парезах // Актуальные научные исследования в современном мире. 2017. № 11-4 (31). С. 100-104.

13. Логвинов Л.А., Кумачев К.В., Кузнецов Г.В., Стояков А.М. Применение ударно-волновой терапии при болезни Пейрони // Андрология и генитальная хирургия. 2011. № 2. С. 134-136.

14. Yee C.H., Chan E.S., Hou S.S., Ng C.F. Extracorporeal shockwave therapy in the treatment of erectile dysfunction: a prospective, randomized, doubleblinded, placebo controlled study // Int. J. Urol. 2014 Oct. Vol. 21 (10). P. 1041-1045. doi: 10.1111/iju.12506.

15. Семевский А.Е., Чистов В.В., Серов Д.Д., Баранов M.C. Новейший опыт применения терапии ударными волнами в различных областях медицины // Доктор Ру. 2009. № 7 (51). С. 32-40.

16. Franco J.V., Turk T., Jung J.H. et al. Nonpharmacological interventions for treating chronic prostatitis/chronic pelvic pain syndrome // Cochrane Database Syst. Rev. 2018 Jan. 26. 1:CD012551. doi: 10.1002/14651858.CD012551.pub2.

17. Al Edwan G.M., Muheilan M.M., Atta O.N. Long term efficacy of extracorporeal shock wave therapy [ESWT] for treatment of refractory chronic abacterial prostatitis // Ann. Med. Surg. (Lond). 2017 Jan 6. Vol. 14. P. 12-17. doi: 10.1016/j.amsu.2016.12.051. eCollection $2017 \mathrm{Feb}$.

18. Antolak S.J., Antolak C.M. Chronic pelvic pain: neurogenic or non-neurogenic? Warm detection threshold testing supports a diagnosis of pudendal neuropathy // Pain Physician. 2018 Mar. Vol. 21 (2): E125-E135.

19. Крупин В.Н., Крупин А.В., Белова А.Н., Нашивочникова Н.А. Состояние гемодинамики предстательной железы у больных с миофасциальным синдромом // Урологические ведомости. 2017. Т. 7, № 4. С. 39-43.

20. Chow I.H., Cheing G.L. Comparison of different energy densities of extracorporeal shock wave therapy (ESWT) for the management of chronic heel pain // Clin. Rehabil. 2007. Vol. 21. P. 131-141.

21. Pontari M.A., Ruggieri M.R. Mechanisms in prostatitis/ chronic pelvic pain syndrome // J. Urol. 2004. Vol. 172 (3) P. 839-845.

22. Zimmermann R., Cumpanas A., Miclea F., Janetschek G. Extracorporeal shock wave therapy for the treatment of chronic pelvic pain syndrome in males: randomised, double-blind, placebo-controlled study // Eur. Urol. 2009 Sep. Vol. 56 (3). P. 418-424.

23. Moayednia A., Haghdani S., Khosrawi S., Yousefi E., Vahdatpour B. Long-term effect of extracorporeal shock wave therapy on the treatment of chronic pelvic pain syndrome due to nonbacterial prostatitis // J. Res. Med. Sci. 2014 Apr. Vol. 19 (4). P. 293-296.

24. Qin X., Lu Y.P. Application of extracorporeal shockwave therapy in andrology // Zhonghua Nan Ke Xue. 2012 Dec. Vol. 18 (12). P. 1125-1129. fering from extrapulmonary tuberculosis lungs. Tuberculosis and Lung Diseases, 2, 46-48. In Russ.

10. Kulchavenya E.V., Khomyakov V.T. (2003). Extra pulmonary tuberculosis in Western Siberia. Tuberculosis and Lung Diseases, 80, 4, 13-15. In Russ.

11. Zhao W.P., Li Y.T., Chen J. et al. (2012). Prostatic calculi influence the antimicrobial efficacy in men with chronic bacterial prostatitis. Asian J. Androl., 14, 5, 715-719. doi: 10.1038/aja.2012.40.

12. Shevelyova N.I., Tarasova N.V. (2017). Use of shock wave therapy in poststroke spastic paresis. Relevant Scientific Research in the Modern World, 11-4, 31, 100-104. In Russ.

13. Logvinov L.A., Kumachev K.V., Kuznetsov G.V., Stoyakov A.M. (2011). Use of shock wave therapy in Peyronie's disease. Andrology and Genital Surgery, 2, 134-136. In Russ.

14. Yee C.H., Chan E.S., Hou S.S., Ng C.F. (2014, Oct). Extracorporeal shockwave therapy in the treatment of erectile dysfunction: a prospective, randomized, double-blinded, placebo controlled study. Int. $J$. Urol., 21, 10, 1041-1045. doi: 10.1111/iju.12506.

15. Semevskii A.E., Chistov V.V., Serov D.D., Baranov M.S. (2009). Recent application of shock wave therapy in various specialities. Doctor $R u, 7,51,32-40$.

16. Franco J.V., Turk T., Jung J.H. et al. (2018). Non-pharmacological interventions for treating chronic prostatitis/chronic pelvic pain syndrome. Cochrane Database Syst. Rev. Retrieved on January 26, 2018 from 1:CDo12551. doi: 10.1002/14651858. CDo12551.pub2.

17. Al Edwan G.M., Muheilan M.M., Atta O.N. (2017, Jan 6). Long term efficacy of extracorporeal shock wave therapy [ESWT] for treatment of refractory chronic abacterial prostatitis. Ann. Med. Surg. (Lond)., 14, 12-17. doi: 10.1016/j.amsu.2016.12.051. eCollection 2017 Feb.

18. Antolak S.J., Antolak C.M. (2018). Chronic pelvic pain: neurogenic or non-neurogenic? Warm detection threshold testing supports a diagnosis of pudendal neuropathy. Pain Physician, 21, 2, E125-E135.

19. Krupin V., Krupin A., Belova A.N., Nashivochnikova N.A. (2017). The state of prostate hemodynamics in patients with myophascial pain syndrome. Urologicheskie Vedomosti, 7, 4, 39-43.

20. Chow I.H., Cheing G.L. (2007). Comparison of different energy densities of extracorporeal shock wave therapy (ESWT) for the management of chronic heel pain. Clin. Rehabil., 21, 131-141.

21. Pontari M.A., Ruggieri M.R. (2004). Mechanisms in prostatitis/chronic pelvic pain syndrome. J. Urol., $172,3,839-845$.

22. Zimmermann R., Cumpanas A., Miclea F., Janetschek G. (2009, Sep). Extracorporeal shock wave therapy for the treatment of chronic pelvic pain syndrome in males: randomised, double-blind, placebo-controlled study. Eur. Urol., 56, 3, 418-424.

23. Moayednia A., Haghdani S., Khosrawi S., Yousefi E., Vahdatpour B. (2014, Apr). Long-term effect of extracorporeal shock wave therapy on the treatment of chronic pelvic pain syndrome due to nonbacterial prostatitis. J. Res. Med. Sci., 19, 4, 293-296.

24. Qin X., Lu Y.P. (2012, Dec). Application of extracorporeal shockwave therapy in andrology. Zhonghua Nan Ke Xue, 18, 12, 1125-1129. 


\section{СВЕДЕНИЯ ОБ АВТОРАХ}

Кульчавеня Екатерина Валерьевна - д-р мед. наук, гл. науч. сотрудник ФГБУ «Новосибирский НИИ туберкулеза» Минздрава России; профессор кафедры туберкулеза ФГБОУ ВО «Новосибирский государственный медицинский университет» Минздрава России.

Шевченко Сергей Юрьевич - врач-уролог ФГБУ «Новосибирский НИИ туберкулеза» Минздрава России; аспирант ФГБОУ ВО «Новосибирский государственный медицинский университет» Минздрава России.

Баранчукова Анжелика Анатольевна - канд. мед. наук, врач кабинета ультразвуковой диагностики ФГБУ «Новосибирский НИИ туберкулеза» Минздрава России; доцент кафедры туберкулеза ФГБОУ ВО «Новосибирский государственный медицинский университет» Минздрава России.

Образец цитирования : Кульчавеня Е.В., Шевченко С.Ю., Баранчукова А.А. Возможности экстракорпоральной ударно-волновой терапии при хроническом простатите / синдроме хронической тазовой боли // Journal of Siberian Medical Sciences. 2018. № 4. C. $13-25$.

\section{ABOUT THE AUTHORS}

Kulchavenya Ekaterina Valeryevna - Dr. Sci. (Med.), Chief Researcher at Novosibirsk Research Institute of Tuberculosis; Professor of the Department of Tuberculosis, Novosibirsk State Medical University.

Shevchenko Sergey Yuryevich - Urologist at Novosibirsk Research Institute of Tuberculosis; Post-graduate Student at Novosibirsk State Medical University.

Baranchukova Anzhelika Anatolyevna - Cand. Sci. (Med.), Doctor of Ultrasonic Diagnostics at Novosibirsk Research Institute of Tuberculosis; Associate Professor of the Department of Tuberculosis, Novosibirsk State Medical University.

Citation example: Kulchavenya E.V., Shevchenko S.Yu., Baranchukova A.A. (2018). Possibilities of extracorporeal shock wave therapy in chronic prostatitis / chronic pelvic pain syndrome. Journal of Siberian Medical Sciences, 4, 13-25. 